\title{
MEDIA SOSIAL DAN KERUKUNAN UMAT BERAGAMA DI BALI (REPRESENTASI MASYARAKAT BALI TERHADAP BERBAGAI POSTING TERKAIT GERAKAN AKSI DAMAI TERKAIT ISU PENISTAAN AGAMA DI MEDIA SOSIAL DAN DAMPAKNYA PADA KERUKUNAN UMAT BERAGAMA DI BALI)
}

\author{
Lukman Nusa \\ Ilmu Komunikasi UIN Sunan Kalijaga Yogyakarta \\ Jl. Marsda Adisucipto Yogyakarta \\ Email: nusalukman@gmail.com
}

\begin{abstract}
The character of social media causes the process of information's dissemination becomes much more unimpeded. The freedom sometimes causes some parties forget about the importance of maintaining harmony among religious people. The are posts founded in the social media that lead to issues of SARA or in this research is related to the case of blasphemy committed by Ahok. The posts in some degree is being reputed as a common one, especially in the territory of Java which is dominated by moslem societies and for some parties it even becomes a necessity to express their voices to defend their religion, or so they say. Then the question is how the representation of Balinese society dominated by the non-moslem societies, react to the posts in Facebook related to the case. The theory of social representation by Moscovisci is used to answer the problem of representation. Case studies with data collection of in-depth interviews is used to analyze Balinese society representation about this issue.
\end{abstract}

Keywords: representations, case study, social media, religious harmony

\section{A. PENDAHULUAN}

Kerukunan umat beragama di Indonesia, belum lama ini sempat terkoyak dengan adanya pernyataan yang oleh beberapa kalangan diklaim sebagai penistaan agama. Berbagai aksi digelar dengan tuntutan pengusutan kasus tersebut ke meja hijau. Pernyataan yang dinilai sebagai penistaan agama tersebut terlontar oleh salah satu tokoh masyarakat non muslim yang sedang menjalani proses pemilihan gubernur di Ibu Kota Indonesia, DKI Jakarta. Pernyataan Basuki Tjahaja Purnama, yang pada saat itu menjabat sebagai gubernur DKI Jakarta, di Kepulauan Seribu pada 27 September 2016 nampaknya membuat geram sebagian besar kelompok umat Islam hingga membuat mereka terdorong untuk melakukan beberapa aksi damai untuk menuntut pengusutan kasus tersebut.

Pada kesempatan tersebut, Ahok meminta warga tidak perlu khawatir soal kelanjutan program tambak ikan di kawasan tersebut. Hal ini karena program tersebut akan tetap berjalan meski dirinya tidak terpilih kembali di Pilkada DKI 2017. Polemik berawal ketika Ahok meminta warga untuk tidak memilihnya kembali, apabila ada sosok pemimpin yang lebih baik darinya. Setelah menyampaikan keuntungan program tambak ikan, Ahok memberikan pernyataan yang dinilai menyinggung umat muslim dengan mengutip OS AlMaidah ayat 51. Rekaman video pernyataan Ahok itu kemudian diunggah oleh Buni Yani ke Youtube pada 6 Oktober 2016. (https://www.cnnindonesia.com/nasional/ 20161124075029-12-174911/kronologikasus-buni-yani-penyebar-video-ahok-soalal-maidah)

Permintaan maaf yang disampaikan Ahok nampaknya dianggap tidak cukup. Selang empat hari dari konferensi pers tersebut, pada tanggal 14 Oktober 2016 
sejumlah organisasi kemasyarakatan keagamaan menggelar aksi unjuk rasa di depan Kantor Badan Reserse Kriminal Polri di kawasan Gambir, dan Gedung Balai Kota DKI Jakarta. Massa yang dipimpin Ketua Front Pembela Islam Rizieq Shihab menuntut, agar aparat hukum mengusut kasus dugaan penistaan agama yang sebelumnya telah dilaporkan ke Bareskrim Polri. Peristiwa ini kemudian dikenal dengan nama Aksi Bela Islam Jilid I. Aksi damai ini nampaknya menjadi awal dari rangkaian aksi-aksi damai lain yang beberapa diantaranya sempat diwarnai dengan kericuhan.

Terkait dengan aksi-aksi damai yang marak dilakukan oleh berbagai kelompok tersebut, nampaknya media sosial memiliki lebih memiliki andil dalam proses pelaksanaan aksi, jika dibandingkan dengan media mainstream. Berbagai fitur dalam media sosial tersebut digunakan untuk mempublikasikan hal-hal terkait dengan gerakan tersebut setidaknya menjadi salah satu alasan pemilihan bentuk media. Selain dapat menyuarakan suara khalayak secara langsung dan tanpa filter, media sosial dianggap memiliki fitur yang lebih kaya jika dibandingkan dengan media mainstream. Sebut saja fitur post yang berupa foto, video hingga optimalisasi tag metadata media sosial dengan menggunakan hastag (\#).

Media mainstream, seperti halnya televisi, radio, koran, majalah, baik yang berupa media konvensional maupun media baru sudah tidak lagi menjadi media pilihan masyarakat. Hal ini bisa jadi disebabkan oleh masyarakat yang mulai sadar akan adanya agenda ataupun framing yang dilakukan oleh media-media konvensional. Seperti halnya hasil penelitian Lukman Nusa (2016) yang menemukan adanya perbedaan agenda setting pada halaman muka majalah Tempo. Dalam penelitian tersebut disebutkan bahwa ditemukan perbedaan isu utama yang diangkat oleh majalah tersebut salam pra-reformasi dan pasca-reformasi. Perbedaan semacam ini dimungkinkan karena adanya perbedaan pendekatan pemerintah terhadap media pada dua masa tersebut. Hal ini menunjukkan bahwa pemerintah, hingga tingkat tertentu mampu mempengaruhi isi dari media tersebut.

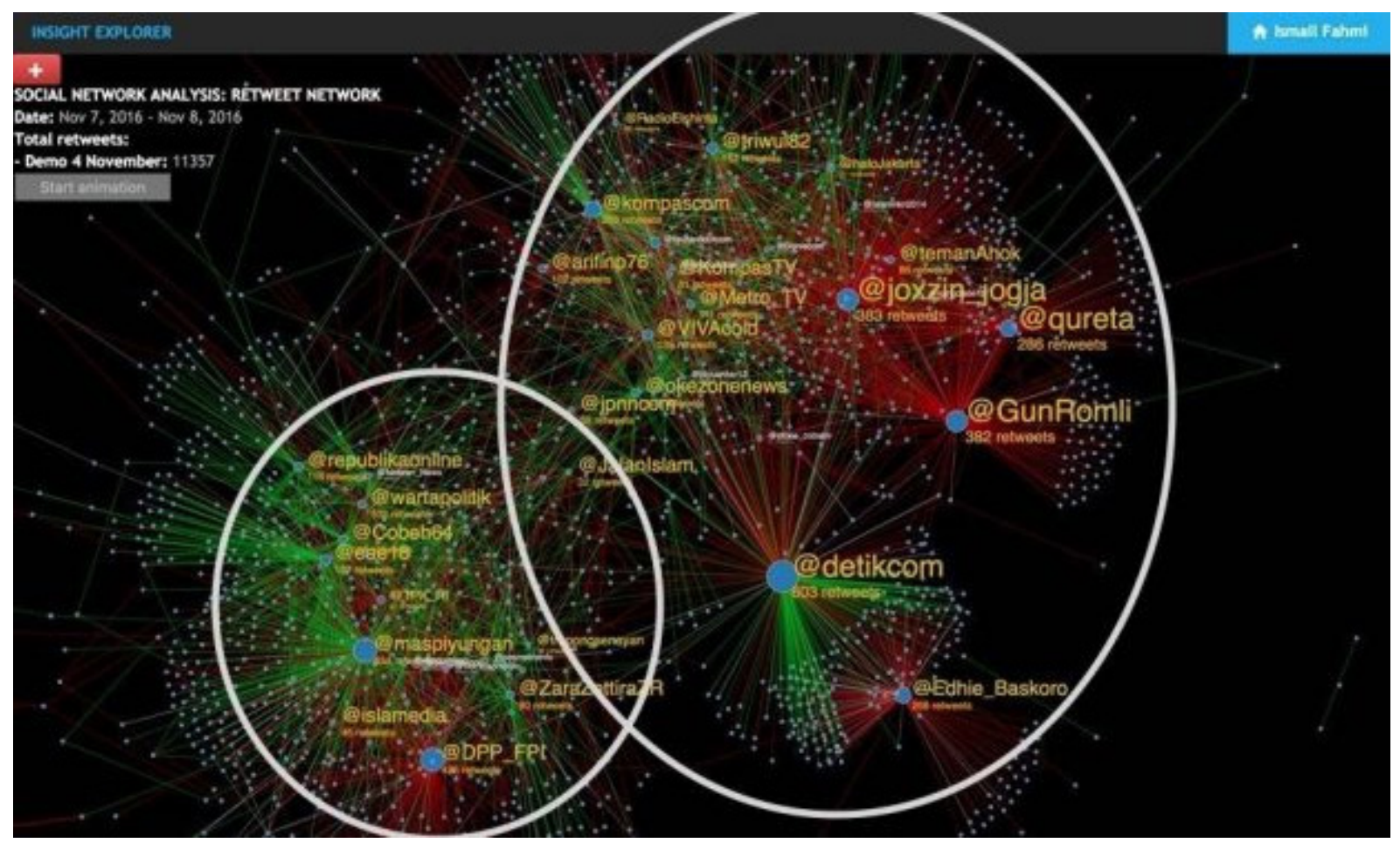

Gambar 1. Peta "Perang Opini" Tuntutan Penghukuman Ahok Terkait Kasus Penistaan Agama

Sumber: Akbarmedia.com 
Lebih lanjut dalam perkembangannya, luasnya internet sebagai core dalam jejaring media sosial, ternyata tidak selalu digunakan untuk menyuarakan keberpihakkannya pada aksi damai tersebut. Banyak ditemukan "perang opini", Pro-kontra aksi yang menuntut penghukuman atas Ahok karena dinilai telah menistakan ayat Al-Quran. Ismail Fahmi, seorang pengamat sosial media yang juga Co-Founder Awasometrics membeberkan peta "pertempuran" itu. Menurutnya, "Selepas aksi 4 November, polaritas pro-kontra kembali menguat. Dan tampak cluster (kubu) yang kontra semakin sistematis dengan dukungan berita-berita dari media besar." Sementara, yang kubu yang pro terlihat stagnan.

Dari tampilan analisis Ismail di atas, titik hijau menunjukkan sentimen positif sedangkan titik merah menandakan sentimen negatif. Dari paparan gambar 1 tersebut diatas terlihat beberapa akun personal maupun media nasional terbelah pada dua kubu. Akun @detikcom @ GunRomli dan @temanAhok tampak mengelompok ke dalam kubu kontra aksi damai 411. Sebaliknya, kelompok pro diisi oleh @republikaonline @DPP_FPI dan @wartapolitik. Analisis tersebut dibuat berdasarkan kata kunci "bela Islam," dan "demo 4 november," pada Selasa (8/11). (http:// www.akbarmedia.com/ 2016/11/ inilah- fakta- mengejutkan- peta- media. html)

Berkaitan dengan maraknya "perang opini" di dunia maya, seolah-olah tidak terlalu berimbas pada kerukunan umat beragama di dunia nyata terutama di pulau jawa pada umumnya, dan Jakarta pada khususnya. Hal ini bisa jadi hingga tingkat tertentu disebabkan oleh umat Islam yang masih menjadi jumlah mayoritas penduduk di wilayah tersebut. Kemudian, hal ini menjadi sesuatu yang menarik untuk dikaji mengenai pandangan masyarakat non muslim dengan komposisi penganut agama dan kepercayaan yang berbeda dengan wilayah di pulau jawa berkaitan dengan maraknya konten media sosial yang kaya akan perdebatan terkait isu penistaan agama Islam ini. Kerukunan umat beragama khususnya antara umat Hindu yang menjadi kelompok mayoritas dengan umat Islam yang menjadi kelompok minoritas menjadi sorotan dalam penelitian ini. Bali setidaknya bisa merepresentasikan segelintir wilayah di Indonesia yang memiliki komposisi penduduk dengan jumlah penganut agama dan kepercayaan yang jauh berbeda dengan komposisi di pulau Jawa. Dari paparan masalah yang sudah disampaikan di atas, pada cara dasarnya penelitian ini ingin menjawab pertanyaan bagaimana pandangan masyarakat Bali yang notabene memiliki karakter masyarakat dengan mayoritas non-Islam terhadap berbagai konten media sosial terkait aksi tuntutan pengusutan kasus penistaan agama Islam

\section{B. METODE}

Pada dasarnya penelitian ini hendak menjawab bagaimana representasi masyarakat Bali berkenaan dengan posting aksi damai yang bertajuk pembelaan terhadap penistaan Ayat Al Quran (OS Al Maidah:21) di media media sosial. Subyek penelitian adalah masyarakat di Pulau Bali yang notabene memiliki karakter masyarakat yang berbeda dengan kelompok-kelompok masyarakat di pulau jawa. Terutama dalam hal agama yang dianut oleh mayoritas masyarakat di daerah tersebut yakni Hindu. Konsumsi informasi dalam media sosial hingga tingkat tertentu akan berimbas pada kaca mata mereka dalam memandang isu tentang penistaan agama tersebut. Lebih lanjut, hal tersebut nantinya akan berimbas pada tindakan mereka dalam menjaga kerukunan umat beragama di lingkungan, terutama bagaimana mereka berkomunikasi dengan umat Islam yang menjadi kelompok minoritas.

Ketertarikan akan hal ini mendorong penelitian yang dilakukan dengan menggunakan metode kualitatif case study research. Case study dianggap dapat digunakan untuk mendapatkan pengetahuan yang mendalam dari masyarakat Bali yang mayoritas memeluk agama Hindu. Penggunaan metode ini juga dapat meminimalisir kemungkinan untuk 
objek penelitian menjadi melebar. Karena case study menurut Berg adalah metode yang secara sistematis menggali informasi tentang seseorang, setting sosial, peristiwa, atau kelompok yang memungkinkan peneliti untuk mengerti bagaimana proses tersebut berlangsung dan berfungsi. (Yin, 2003). Teknik pengumpulan data dilakukan dengan wawancara mendalam. Wawancara dilakukan terhadap 6 informan untuk mendapatkan data terkait dengan penggunaan media sosial serta bagaimana proses representasi terbentuk.

\section{HASIL DAN PEMBAHASAN}

\section{Penggunaan Facebook sebagai Media Sosial oleh Informan}

Berdasarkan hasil penelitian dapat diketahui bahwa seluruh informan memang pengguna media sosial Facebook dan sudah tidak asing dengan kehadiran media sosial tersebut, meskipun di antara beberapa informan masih terhitung pasif dalam mengakses laman Facebook. Walaupun demikian, keragaman dalam frekuensi penggunaan media sosial tersebut ditemukan. Di samping itu, informasi yang ingin didapatkan juga berbeda-beda, seperti informasi terkait isu-isu terbaru di indonesia maupun di luar negeri, berkomunikasi dengan kolega, ataupun sekedar untuk kepentingan hiburan.

Dari keenam informan dapatlah kiranya disimpulkan bahwa Facebook masih digunakan baik di kalangan orang tua maupun pemuda, walaupun intensitas penggunaannya semakin berkurang seiring muda-nya generasi informan yang bersangkutan. Generasi pemuda nampaknya mulai beralih ke media sosial Instagram jika dibandingkan dengan Facebook. Hal ini bisa jadi merupakan indikasi dari pembuktian bahwa budaya populer memang tidak bertahan lama. Perubahan dan inovasi akan menggeser media sosial lama dengan media sosial baru yang merupakan salah satu produk dari budaya populer. Motif penggunaan dari media sosial Facebook pun beragam, mulai dari media penghubung dengan kolega, media hiburan, dan sarana mencari informasi hingga bisnis.

Terkait dengan media baru, pintu masyarakat untuk berpartisipasi secara aktif dalam sebuah pengembangan sebuah isu menjadi semakin terbuka lebar. Hal ini dimungkinkan dengan adanya konsumsi media baru. Shah (2007) setidaknya mengindikasikan bahwa penggunaan media berita dapat meningkatkan pengetahuan dan kesadaran tentang isu-isu sosial. Hal ini dimungkinkan bisa terjadi karena media baru dapat memberikan sumber dan ruang bagi dikusi mengenai isu-isu yang sedanng berkembang. Tipe diskusi ini yang nantinya aan membantu masyarakat untuk menyelesaikan permasalahanpermasalahan kolektif dan membantu dalam pengambangan partisipasi dalam berbagai hal dalam masyarkat (Walsh, 2004). Lebih lanjut lagi mengenai hal ini, kajian mengenai efek konsumsi media baru menemukan bahwa ternyata menimbulkkan dampak positif dalam partisipasi politik baik secara langsung maupun tidak langsung (Shah, 2007; Cho, 2009; Gil de Zúñiga, Veenstra, Vraga, \& Shah, 2010)

\section{Proses Anchoring Praktek Intoleransi di Media Sosial Facebook}

$$
\text { Moscovici dalam Putra (2003) }
$$

mengidentifikasi proses representasi pertama yakni anchoring, yaitu proses yang mengacu pada pengintegrasian informasi-informasi baru. Masing-masing informan memiliki pendapat yang berbedabeda mengenai Intoleransi. Informan 1 (I Gusti S. Budiaman) menerjemahkan intoleransi sebagai sebuah tindakan yang dimaksudkan untuk mencela sesuatu yang berbeda. Pernyataan senada nampaknya ditemukan dari informan 5 (Sheila Ayu Yulianisa) yang mengartikan intoleransi sebagai tindakan tidak empati pada sesuatu yang berbeda dari dirinya. Informan 2 (Mangku Pasek Swastika) menambahkan perbedaan yang diterjemahkan oleh dua informan sebelumnya menjadi sesuatu yang menimbulkan fanatisme berlebihan, sehingga muncul pandangan bahwa yang berbeda dari dirinya itu salah. Hal ini juga 
didudukung oleh pernyataan informan 4 (Estri Prabiyati) yang berpendapat bahwa intoleransi adalah sikap tidak percaya atas perbedaan pendapat, politik, sikap atau perbedaan agama. Informan 6 (Niluh Putu Wahyu Widyastiti Sudarsana) memperkuat pandangan informan-informan sebelumnya dengan menerjemahkan intoleransi sebagai sikap acuh dan tidak menghargai, tidak simpati, tidak merangkul dan tidak saling menyayangi.

Berdasarkan pendapat tersebut nampaknya dapatlah kiranya disimpulkan bahwa seluruh informan pada dasarnya memahami apa yang dimaksud dengan intoleransi. Dari pandangan-pandangan para reponden, intoleransi dimaknai sebagai sikap yang diutarakan untuk menolak ataupun menyangkal hal yang tidak sesuasi dengan pandangan-nya. Perbedaan pandangan initidak muncul begitu saja, akan tetapi disebabkan oleh sikap acuh dan tidak menghargai yag menyebabkan munculnya sebuah sikap fanatisme berlebihan yang kemudian akan memacu adanya anggapan bahwa dirinya lah yang paling benar dan orang lain lah yang salah. Senada dengan hal tersebut, norma, ajaran, pemahaman, sikap dan persepsi telah diidentifikasikan sebagai penyebab munculnya tindakan intoleransi (Ahmad, 2013)

Intoleransi bisa jadi sebuah permasalahan utama dalam menjaga kerukunan yang selanjutnya dapat menjadi pondasi persatuan rakyat dan bangsa Indonesia. Tanpa terwujudnya kerukunan diantara berbagai Suku, Agama, Ras dan antar Golongan bangsa Indonesia akan mudah terancam oleh perpecahan dengan segala akibatnya yang tidak diinginkan. Kerukunan antar agama merupakan salah satu pilar utama dalam memelihara persatuan bangsa dan kedaulatan negara Republik Indonesia. Kerukunan sering diartikan sebagai kondisi hidup dan kehidupan yang mencerminkan suasana damai, tertib, tentram, sejahtera, hormat menghormati, harga menghargai, tenggang rasa, gotong royong sesuai dengan ajaran agama dan kepribadian pancasila (Depag $\mathrm{RI}, 1997: 8$ dan 20)
Kata kerukunan berasal dari bahasa arab ruknun (rukun) kata jamaknya adalah arkan yang berarti asas, dasar atau pondasi (arti generiknya). Dalam bahasa Indonesia arti rukun ialah:

1. Rukun (nominal), berarti: Sesuatu yang harus di penuhi untuk sahnya pekerjaan, seperti tidak sahnya manusia dalam sembahyang yang tidak cukup syarat, dan rukunya asas, yang berarti dasar atau sendi: semuanya terlaksana dengan baik tidak menyimpang dari rukunnya agama.

2. Rukun (ajektif) berarti: Baik dan damai tidak bertentangan: hendaknya kita hidup rukun dengan tetangga, bersatu hati, sepakat. Merukunkan berarti: (1) mendamaikan; (2) menjadikan bersatu hati. Kerukunan: (1) perihal hidup rukun; (2) rasa rukun; kesepakatan: kerukunan hidup bersama. (Syaukani, 2008:5)

Selanjutnya, deskripsi informan terhadap intoleransi menggambarkan bagaimana pemahaman informan terhadap praktek intoleransi. Dalam penelitian ini, informan diminta untuk mendeskripsikan juga mengenai batasan tindakan yang bersifat intoleransi yang mereka pahami. Informan 1 (I Gusti S. Budiaman) mendiskripsikan tindakan intoleransi dapat berupa perkataan hingga perbuatan yang mencela dan juga sampai pada berusaha untuk menghalangi sesuatu yang berbeda dengan prinsip seseorang. Sama halnya dengan informan 1, informan 6 (Niluh Putu Wahyu Widyastiti Sudarsana) menggarisbawahi intoleransi sebagai bentuk ucapan melecehkan sesuatu yang berbeda atau tidak sesuai dengan diri seseorang. Informan 2 (Mangku Pasek Swastika) menambahkan definisi tersebut dengan tindakan radikal, mengucilkan dan juga bermaksud menyerang kelompok dengan ideologi, paham ataupun agama lain,baik secara langsung ataupun tidak, secara frontal ataupun tertutup.

Empat dari enam informan nampaknya paham pada tataran konsep dari tindakantindakan intoleransi. Disamping empat informan tersebut, dua informan yang lain, 
mampu untuk mengkategorikan tindakan disekitar mereka sebagai bentuk dari intoleransi. Dapatlah kiranya disimpulkan di sini bahwa mayoritas informan mampu untuk mendefinisikan konsep tindakan intoleransi. Tataran kemampuan mengidentifikasi tindakan intoleransi yang menurut hemat penulis sebagai tataran yang lebih tinggi baru ditemukan pada sebagian informan. Kemampuan mengidentifikasi tindakan-tindakan intoleransi inilah yang dapat meminimalisir terjadinya tindakan intoleransi sampai tingkat tertentu mungkin ditemukan disekitar informan.

Selanjutnya, argumen dari masingmasing informan baru sebatas pemahaman akan konsep dan kemampuan informan untuk mengidentifikasi tindakan yang menurutnya adalah tindakan intoleransi. Disamping kedua hal tersebut, informan diminta untuk berpendapat mengenai berbagai alasan terjadinya tindak intoleransi. Informan 1 (I Gusti S. Budiaman) menyatakan bahwa tindak intoleransi bisa jadi disebabkan oleh ketidakpahaman terhadap perbedaan. Senada dengan hal itu, informan 5 (Sheila Ayu Yulianisa), menambahkan bahwa ketidakpemahaman dan ketidakacuhan seseorang terhadap permasalahan yang ada dapat menyebabkan seseorang melakukan tindakan intoleransi. Disamping ketidakpahaman dan ketidakacuhan seseorang, pemikiran dan tidak bijaknya seseorang menanggapi suatu nampaknya juga menjadi penyebab terjadinya tindak intoleransi. Hal ini lah yang diidentifikasi oleh informan 2 (Mangku Pasek Swastika) sebagai penyebab tindakan itu.

Selanjutnya, permasalahan tindak intoleransi ini dapat menjadi permasalahan yang besar, jikalau pihak yang bersangkutan tidak bijak menanggapi hal tersebut. Sepertihalnya informan 3 (Abdul Karim Abraham) yang berpendapat bahwa "intoleransi bisa terjadi jika ada oknum yang membesarkan masalah yang kecil dan menyinggung istilah SARA dan labelling lainnya". Senada dengan informan 3, informan 6 (Niluh Putu Wahyu Widyastiti Sudarsana) menyebutkan bahwa membesar-besarkan sesuatu isu yang ada tanpa memverifikasi kebenarannya dapat menyebabkan terjadinya intoleransi yang semakin memperparah keadaan.

Deskripsi informan-informan di atas sekilas terlihat memiliki makna yang relatif sama terkait alasan munculnya praktek intoleransi meskipun dilihat melalui sudut pandang yang berbeda. Benang merah yang dapat ditarik berdasarkan argumen informan di atas yakni alasan munculnya intoleransi tidak terlepas dari adanya perbedaan pendapat seseorang dalam memandang suatu kasus dan cara mereka dalam merespon kasus tersebut. Di samping itu, singgungan-singgungan seperti unsur SARA dan labelling lainnya ikut masuk pada cara seseorang membaca suatu isu yang tengah terjadi di masyarakat masing-masing informan menggambarkan bentuk praktek intoleransi yang berbedabeda, walaupun gambaran yang dijelaskan sangat erat kaitannya dengan adanya sikap saling membedakan antara satu hal dengan hal yang lain.

Senada dengan hal itu, De Fleur (dalam Setiaman, 2008) dan Roy (2011) menyatakan bahwa individu yang termasuk dalam golongan sosial tertentu atau sama akan cenderung memiliki pemahaman, penilaian, sikap dan perilaku yang kurang lebih sama terhadap rangsangan-rangsangan tertentu. Dalam hal temuan penelitian Sirupa Roy di India, pesan-pesan yang disampaikan media massa cenderung ditanggapi secara kurang lebih sama oleh individu yang termasuk dalam golongan sosial yang sama. Adanya kesamaan ini nantinya akan berimbas pada perkembangan sektor sosial, ekonomi, dan politik yang sifatnya khas pada tiap kota di India yang oleh Sirupa Roy hal ini dikatakan sebagai Provincializing Effect.

\section{Proses Objectification Praktek Intoleransi di Media Sosial Facebook}

Objectifications merupakan proses lanjutan dari anchoring dalam konsep representasi sosial yang disampaikan oleh Moscovici (Putra:2003). Objectifications sendiri bermakna sebagai sebuah proses yang merujuk pada pemaknaan ide yang 
masih dalam tataran konsep dan tidak jelas menjadi sesuatu yang lebih berwujud atau kongkrit. Berkaitan dengan penelitian ini, proses tersebut dikaitkan dengan identifikasi informan pada berberbagai praktek intoleransi yang ditemukannnya dalam media sosial Facebook, terutama terkait dengan isu penistaan agama yang dilakukan oleh mantan gubernur Basuki Tjahja Purnama (Ahok).

\section{Bentuk Intoleransi dalam Facebook}

Menanggapi pertanyaan mengenai berbagai posting mengenai isu penistaan agama, informan 1 (I Gusti S. Budiaman) mengaku mencari berita mengenai kasus tersebut baik di media sosial Facebook maupun melalui mesin pencari Google. "Ya saya banyak menemukan posting mengenai penistaan agama Ahok dan juga tuntutan-tuntutan pengusutan kasus tersebut di Facebook, biar lebih jelas soal postingan saya selalu kroscek di mediamedia lain melalui Google." Pernyataan semacam ini mengindikasikan bagaimana aktifnya informan 1 dalam mencari informasi mengenai isu penistaan agama tersebut dalam media sosialnya. Dalam mengkonsumsi informasi, nampaknya informan 1 melakukan disiplin verifikasi. Hal ini nampak dari bagaimana informan merespon berita atau informasi yang diterima dalam media sosial dan tidak langsung percaya pada apa yang dibacanya akan tetapi melakukan verifikasi dengan cara mencari informasi-informasi lain terkait dengan postingan dalam media sosial tersebut dari sumber lain, yakni Google. Google sendiri merupakan mesin pencari dalam World Wide Web yang memungkinkan penggunanya mencari informasi mengenai berbagai hal hanya dengan memasukkan keyword dalam kolom tersendiri. Adanya mesin pencari ini memudahkan seseorang untuk mengakses informasi yang tersebar diberbagai penjuru dunia dalam hitungan detik.

Bila informan 1 tidak menjelaskan keberpihakannya dalam aksi tuntutan pengusutan kasus penistaan agama, informan 2 (Mangku Pasek Swastika) secara gamblang menyatakan persetujuannya dalam tindak lanjut kasus penistaan agama oleh Ahok. "ya memang perlu di selesaikan kasus seperti itu, kasus lain saja ditangkap dulu baru di periksa." Pernyataan semacam ini dapat diartikan bahwa informan 2 menganggap bahwa kasus penistaan agama yang melibatkan Ahok (gubernur non-aktif DKI Jakarta pada saat itu) sama seperti halnya kasus-kasus lain yang memerlukan investigasi dalam penyelesaiannya. Terlepas adanya beberapa kecurigaan beberapa kelompok yang mensinyalir adanya muatan politik dalam tuntutan pengusutan kasus penistaan agama oleh Ahok. Beberapa kalangan peserta aksi bela islam pun menepis adanya tuntutan mengenai hal ini dengan menggunaakan beberapa meme.

Terkait dengan bentuk-bentuk postingan mengenai isu penistaan agama. Informan 1 yang mengaku memang mencari berita mengenai perkembangan kasus Ahok tersebut baik dari media sosial Facebook miliknya, maupun dari mesin pencari Google. "dulu sering saya temukan berbagai share dari beberapa teman saya di halaman Facebook, paling sering berbentuk artikel yang isinya seruan-seruan dalam membela agama beserta alasan-alasannya." Berangkat dari pernyataan informan 1 tersebut, beberapa pertanyaan tambahan muncul untuk mendapatkan detailyang lebih dalam mengenai hal ini, yakni mengenai bentuk-bentuk lain postingan yang ada di halaman Facebook yang berkaitan dengan isu penistaan agama. "Kalau bentuk lain mungkin saya kurang memperhatikan, dek. Oh ya, meme dan video mungkin yah, ada beberapa kali saya temukan."

Dari pernyataan informan 1 tersebut di atas, dapatlah kiranya disimpulkan bahwa bentuk-bentuk penyebaran informasi mengenai isu penistaan agama di Facebook berupa artikel, meme dan video. Terkait dengan tiga bentuk postingan tersebut, ada bentuk yang menarik yakni meme. Meme sendiri diartikan sebagai sebuah bentuk peniruan yang sering ditujukan untuk olokolokan atau sindiran pada suatu fenomena yang menjadi perhatian publik. Berkaitan dengan hal ini, informan 1 mengutarakan 
bahwa gambar meme yang paling sering ditemukan adalah foto dari Ahok dengan beberapa tulisan mengenai penistaan agama. "Bentuk memenya beragam sih dek, yang paling saya ingat itu foto Ahok lalu diberi tulisan jangan mau dibohongi pake ayat-ayat Al Quran." Meme semacam ini, menurut hemat penulis dapat hingga tingkat tertentu dapat menyulut emosi beberapa kalangan.

Berkaitan dengan hal tersebut, informan 6 (Niluh Putu Wahyu Widyastiti Sudarsana) membenarkan bahwa memang ditemukan beberap postingan dalam media sosial Facebook miliknya terkait dengan pengusutan kasus penistaan agama yang dilakukan oleh Ahok. "Dulu sering menemukan postingan terkait Basuki Tjahaja Purnama baik dalam bentuk poster digital maupun dalam bentuk vidio singkat, postingan berbentuk "seruan aksi untuk membela islam melawan penista agama", tapi banyak yang tidak saya pahami karena banyak istilah Islam dalam postingan tersebut." Poster digital yang dimaksud oleh Niluh Putu Wahyu Widyastiti Sudarsana ini merupakan salah satu bentuk meme yang menurut Bauckhage (2011) merupakan sebuah produk dari komentar-komentar netizen yang berusaha mengimitasi secara tepat atau bahkan memparodikan, baik dalam bentuk dibesar-besarkan ataupun dikecil-kecilkan dalam pengertian satiris, informasi yang mereka dapatkan dari berbagai media. Meme ini kemudian menjadi sebuah barang yang lumrah diproduksi oleh pengguna internet (internet user). Shifman (2013) sendiri bahkan mengidentifikasi meme sebagai bentuk propaganda yang memang berbentuk lelucon satiris.

\section{Reaksi Terhadap Post dalam Facebook}

Berkaitan dengan reaksi terhadap berbagai postingan dalam media sosial Facebook nampaknya informan memiliki sudut pandang yang berbeda-beda. Hal ini dimungkinkan disebabkan oleh latar belakang yang dimiliki oleh masingmasing informan. Pandangan mengenai masih relevannya berbagai posting yang ditemukan dalam media sosial Facebook nampaknya disampaikan oleh Informan 2 (Mangku Pasek Swastika) dengan pernyataan bahwa postingan tersebut merupakan bentuk tututan yang memang wajar dilakukan bila terjadi dalam agamanya. "ya memang perlu diselesaikan kasus seperti itu, kasus lain saja di tangkap dulu baru di periksa." Pernyataan semacam ini dapat diartikan bahwa informan menganggap bahwa kasus penistaan agama tersebut tidak ada bedanya dengan kasus-kasus lain yang sejenis, dimana diperlukan proses hukum dengan mengadakan penangkapan pada terdakwa pada kasus terkait.

Sejalan dengan hal tersebut, informan 6 (Niluh Putu Wahyu Widyastiti Sudarsana) menyetakan empatinya terhadap kasus penistaan agama tersebut. Menurutnya, adanya berbagai tuntutan berupa aksiaksi tersebut memang lumrah dilakukan karena menyangkut dengan agama yang dianutnya. Informan merespon dengan pernyataan "wajar saja sih ada kemarahan dari pihak islam, karena biarpun sedikit Ahok tetap salah". Pernyataan semacam ini menunjukkan adanya empati yang ada dalam diri informan. Perasaan ketika agamanya sendiri ternoda oleh perkataan pihak lain yang tidak seagama.

Informan lain yang senada dengan persetujuan mengenai aksi bela Islam terkait kasus penistaan agama oleh Ahok adalah informan 3 (Abdul Karim Abraham). Menurutnya berbagai aksi tuntutan pengusutan penistaan agama tersebut memang sepatutnya dilakukan. Pernyataan yang bernada affirmative tersebut dinyatakan dengan rencana keikutsertaan informan 3 dalam berbagai aksi tuntutan pengusutan kasus penistaan agama. Informan menyatakan "Kasus di Bali berbeda dengan di Jakarta, Ahok memang salah, sedangkan kalau di bali memang dari dulu tidak pernah ramai ribut antar Islam dengan Hindu, kadang yang ribut antara Hindu dengan Hindu sendiri, Bali toleran kalau antar agama, kalau sesama kadang masih suka ribut, tapi tidak besar kasusnya, dimanapun sama, asal tidak macam macam ya tidak akan diusik, soal kasus Ahok kalau 
saya pikir ya wajar lah, saya juga ikut ke Jakarta untuk ikut aksi itu, InsyaAllah tahun 2017 saya ikut lagi." Pernyataan semacam ini muncul ketika informan memang berlatar belakang Islam.

Aksi damai sendiri merupakan bentuk dari kebebasan yang dijamin oleh sistem Demokrasi. Demokrasi sendiri yang nampaknya dianut oleh sistem politik di Indonesia mengalami perkembangan yang signifikan. Perkembangan demokrasi juga tidak dapat terlepas dari peran pers atau media massa. Oleh Curran dalam Pawito (2009: 101), fungsi media berkenaan dalam pengembangan demokrasi dijabarkan pertama menjadi fungsi informasi, dimana fungsi ini merujuk pada pengembangan dari fungsi pers yang tidak saja ditujukan untuk melaporkan kejadian-kejadian akan tetapi juga dituntut untuk mampu menumbuhkan berbagai pemahaman terhadap peristiwa-peristiwa tersebut, kedua fungsi representasi, dimana fungsi ini menuntut media massa untuk mampu cover both side dalam tiap laporan peristiwaperistiwa, dan ketiga fungsi membantu mencapai tujuan bersama masyarakat yang menuntut media massa bukan saja agar mampu melaporkan ketidakberesan yang terjadi dalam pemerintah akan tetapi juga dapat mempromosikan dan memfasilitasi tiap prosedur demokratik bagi masyarakat.

Nilai-nilai demokrasi yang sering dipahami berasal dari kata Yunani, demos (people) dan kratos (rule). Demokrasi nampaknya mengalami pergeseran dari waktu ke waktu. Terlepas dari semuanya itu, sebuah kesulitan tersendiri muncul dalam pendiskripsian tentang demokrasi. Pergeseran konsep tentang kata ini setidaknya menjadi sebuah persoalan. $\mathrm{Hal}$ ini berangkat dari sebuah kenyataan bahwa proses adaptasi konsep demokrasi dari wilayah satu dengan wilayah yang lain sangat berbeda. Akan tetapi secara garis besar, bukanlah menjadi sebuah kesalahan ketika demokrasi digeneralisasikan sebagai sistem yang memungkinkan adanya jaminan hak pilih terhadap semua warga negara. Selain itu, kebebasan untuk membentuk dan bergabung dalam sebuah organisasi bukan menjadi larangan. Kebebasan pers dan dalam hal ini adalah kebebasan dalam mengakses informasi nampaknya juga menjadi syarat mutlak adanya sistem demokrasi (Caltagirone dalam Magill, 1996: 355). Ketiga generalisasi dari Caltagirone setidaknya dapat memberikan sebuah gambaran tentang adanya demokrasi dalam sebuah wilayah. Pencideraan dari salah satu aspek tersebut, terlepas dari baik dan buruk akibat yang ditimbulkannya, nampaknya menjadi sebuah warna tersendiri dari gerakan perkembangan demokrasi dalam sebuah masyarakat.

Selanjutnya, kompetisi atau kontes ideologi dalam proses demokrasi nampaknya hampir selalu menghasilkan pemenang yang berasal dari kaum mayoritas yang oleh karenanya otoritas selalu berpihak kepada kelompok tersebut. Selain keberpihakan otoritas pada pihak mayoritas, demokrasi juga menuntut adanya perlindungan terhadap kaum minoritas. Adanya fakta semacam ini, isuisu mengenai kebebasan (freedom) dan persamaan (equality) nampaknya menjadi barang wajib dalam perdebatan yang mewarnai perkembangan demokrasi. Hal ini berangkat dari sebuah fakta bahwa dalam tiap pengambilan keputusan atau kebijakan pemerintahan selalu melibatkan pertentangan kepentingan dan ideologi yang nampaknya hampir selalu dimenangkan oleh kaum mayoritas. Menjadi sebuah kesulitan tersendiri memang, akan tetapi pengambilan keputusan semacam ini nampaknya memungkinkan tidak tercakupnya semua kebutuhan kepentingan dari tiap golongan, baik mayoritas maupun minoritas, yang oleh karenanya hingga tingkat tertentu seringkali kebebasan (freedom) kaum minoritas dikorbankan. Halhal semacam inilah yang memicu adanya perdebatan tentang persamaan (equality) dalam praktek-praktek sistem demokrasi (Harisson dalam Craig, 1998: 867-870; Minogue dalam Kuper, 1996: 172-173)

Nampaknya tidak semua informan menyatakan persetujuannya terhadap aksi 
menuntut pengusutan kasus penistaan agama oleh Ahok yang dibingkai pada media sosial Facebook. Beberapa diantaranya adalah informan 4 (Estri Prabiyati) yang menyatakan bahwa memang dalam media sosial Facebooknya, informan yang bersangkutan sering menemukan postingan mengenai bela islam berupa foto dan artikel postingan share seseorang berupa GIF image dan video yang bermaksud untuk mengajak membela islam dalam kasus penistaan agama oleh Ahok. Menurutnya hingga banyak postingan mengenai kasus tersebut mengandung banyak pengecaman. Menurutnya, berbagai bentuk pengecaman ini hendaknya dikurangi bagi kepentingan bersama. "menurut saya memang perlu untuk dilakukan pengusutan mengenai hal itu, akan tetapi bentuk2 pengecaman hendaknya memang harus dikurangi."

Senada dengan pernyataan informan 4, informan 5 (Sheila Ayu Yulianisa) menyatakan nada ketidaksetujuannya pada berbagai reaksi kasus penistaan agama oleh Ahok. Menurutnya, reaksi dalam Facebook merupakan reaksi yang berlebihan. "sering sih melihat postingan berupa vidio pendek di timeline Facebook, kalau itu menurut saya berlebihan, karena ada beberapa yang mengandung kata-kata yang menyerang agama lain." Sindiran menjadi sesuatu yang biasa dalam dunia maya. Hal ini bisa jadi disebabkan oleh adanya kebebasan yang ditawarkan dari dunia maya itu sendiri.

\section{KESIMPULAN}

Pada dasarnya, penelitian ini hendak menjawab pertanyaan bagaimana pandangan masyarakat Bali yang notabene mayoritas non-Islam terhadap berbagai konten media sosial terkait aksi tuntutan pengusutan kasus penistaan agama Islam. Untuk menjawab pertanyaan tersebut, digunakan teori representasi sosial yang dirumuskan oleh Moscovici dalam Putra (2003). Respresentasi sosial sendiri dibagi menjadi dibagi menjadi 2 proses, yang pertama yakni Anchoring yaitu proses yang mengacu pada pengintegrasian informasiinformasi baru, dan kedua Objectifications atau proses yang mengacu pada penerjemahan ide yang abstrak dari suatu objek kedalam gambaran tertentu yang lebih kongkrit.

Pada tahapan Anchoring seluruh informan pada dasarnya memahami apa yang dimaksud dengan intoleransi. Dari pandangan-pandangan para informan, intoleransi dimaknai sebagai sikap yang diutarakan untuk menolak ataupun menyangkal hal yang tidak sesuasi dengan pandangan-nya. Perbedaan pandangan ini tidak muncul begitu saja, akan tetapi disebabkan oleh sikap acuh dan tidak menghargai yang menyebabkan munculnya sebuah sikap fanatisme berlebihan yang kemudian akan memacu adanya anggapan bahwa dirinya lah yang paling benar dan orang lain lah yang salah.

Tahapan Objectifications mengidentifikasi kemampuan informan dalam mengkategorikan praktek intoleransi yang ditemukan dalam media sosial Facebook. Dapatlah kiranya disimpulkan bahwa fitur dalam media sosial Facebook memberikan keleluasan bagi penggunanya dalam menyebarkan berbagai informasi yang dianggapnya penting. Bentuk-bentuk penyebaran berupa artikel, gambar berupa foto maupun meme, dan juga video nampaknya menjadi pilihan bagi para penggunan Facebook dalam menyebarkan informasi di media sosial Facebook.

\section{DAFTAR PUSTAKA}

Ahmad, Haidlor Ali. (2013). Survei Nasional Kerukunan Umat Beragama di Indonesia. Jakarta: Puslitbang Kehidupan Keagamaan Badan Litbang dan Diklat Kementerian Agama RI

Bauckhage, Christian (2011). Insight into Internet Memes. Proceedings of the Fifthr International AAAI Conference on Weblogs and Social Media, 42-49 
Caltagirone, Harry. 1996. Democracy dalam Magill, Frank N (ed.). International Encyclopedia of Government and Politics Vol 1. London: Salem Press Inc

Cho, J., Shah, D. V., McLeod, J. M., McLeod, D. M., Scholl, R. M., \& Gotlieb, M. R. (2009). Campaigns, Reflection, and Deliberation: Advancing an O-S-R-O-R Model of Communication Effects. Communication Theory, 19(1), 66-88. doi: 10.1111/j.14682885.2008.01333.

Depag RI. (1997).Bingkai Teologi Kerukunan Hidup Umat Beragama Di Indonesia, (Jakarta; Badan Penelitian dan Pengembangan Agama Proyek Peningkatan Kerukunan Umat Beragama di Indonesia.

Gil de Zúñiga, H., Veenstra, A., Vraga, E., \& Shah, D. (2010). Digital Democracy: Reimagining Pathways to Political Participation. Journal of Information Technology \& Politics, 7(1), 36-51. doi: 10.1080/19331680903316742

Harisson, Ross. (1998). Democracy dalam Craig, Edward (general editor). Routledge Encyclopedia of Philosophy Vol 2. London, New York: Routledge

Minogue, Kenneth. (1996). Democracy dalam Kuper, Adam dan Jessica Kuper (eds.). The Social Science Encyclopedia $2^{\text {nd }}$ Ed. London, New York: Routledge

Nusa, Lukman. (2016). HALAMAN MUKA MAJALAH TEMPO (Studi Analisis isi Perbedaan Halaman Muka Sebagai Representasi Tajuk Utama Majalah Tempo Edisi Tahun 1993/1994 dengan Tahun 2009/2010). Profetik: Jurnal Komunikasi Vol 9. No 1, 22-31

Pawito. (2009). Pengaruh Talkshow Televisi - Kajian tentang Minat serta Pengaruh Menonton Acara Talkshow Televisi di Surakarta Periode Pemilihan Umum Legislatif 2009, dalam Komunika - Majalah Ilmiah Komunikasi dalam Pembangunan Vol. 14, No.1. 2011. Jakarta: LIPI Press

-. (2009). Komunikasi Politik - Media Massa dan Kampanye Pemilihan. Yogyakarta: Jalasutra

Puslitbang Kehidupan Beragama. (2009). Kompilasi Kebijakan dan Peraturan PerundangUndangan Kerukunan Umat Beragama. Jakarta: Prasasti

Roy, Sirupa. (2011). Television News and Democratic Change in India dalam Media Culture Society july 2011 vol. 33 no. 5 761-777. USA: University of Massachusetts.

Setiaman, Agus. 2008. Kajian Media Massa. Wordpress.com

Shah, D. V., Cho, J., Nah, S., Gotlieb, M. R., Hwang, H., Lee, N.-J., . . McLeod, D. M. (2007). Campaign Ads, Online Messaging, and Participation: Extending the Communication Mediation Model. Journal of Communication, 57(4), 676-703. doi: 10.1111/j.14602466.2007.00363.x

Shah, D. V., Kwak, N., \& Holbert, R. L. (2001). "Connecting" and "Disconnecting" With Civic Life: Patterns of Internet Use and the Production of Social Capital. Political Communication, 18(2), $141-162$.

Shah, D. V., McLeod, J. M., \& Lee, N.-j. (2009). Communication Competence as a Foundation for Civic Competence: Processes of Socialization into Citizenship. Political Communication, 26(1), 102-117. doi: 10.1080/10584600802710384

Shah, D. V., McLeod, J. M., \& Yoon, S.-H. (2001). Communication, Context, and Community. Communication Research, 28(4), 464-506.

Shifman, Limor.(2013). Memes in a Digital World: Reconciling with a ConceptualTroublemaker. Journal of Computer-Mediated Communication, 362-377 
Walsh, K. C. (2004). Talking about politics: Informal groups and social identity in American life: University of Chicago Press.

Yin, Robert K. (2003). Case Study Research: Design And Method, vol 5. London: Sage Publication.

http://www.akbarmedia.com/2016/11/inilah-fakta-mengejutkan-peta-media.html https://www.cnnindonesia.com/nasional/20161124075029-12-174911/ kronologi-kasusbuni-yani-penyebar-video-ahok-soal-al-maidah 